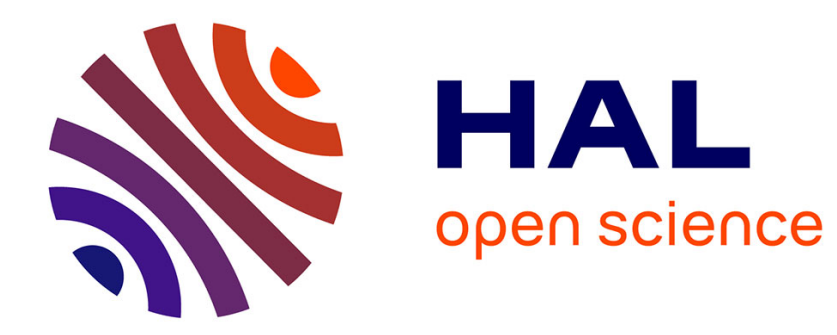

\title{
Puzzling out the Middle-to-Upper Palaeolithic transition
}

William E. Banks

\section{To cite this version:}

William E. Banks. Puzzling out the Middle-to-Upper Palaeolithic transition. Nature Ecology \& Evolution, 2020, 4 (6), pp.775-776. 10.1038/s41559-020-1162-1 . hal-02883383

\section{HAL Id: hal-02883383 https://hal.science/hal-02883383}

Submitted on 12 Nov 2020

HAL is a multi-disciplinary open access archive for the deposit and dissemination of scientific research documents, whether they are published or not. The documents may come from teaching and research institutions in France or abroad, or from public or private research centers.
L'archive ouverte pluridisciplinaire HAL, est destinée au dépôt et à la diffusion de documents scientifiques de niveau recherche, publiés ou non, émanant des établissements d'enseignement et de recherche français ou étrangers, des laboratoires publics ou privés. 
1 Archaeology: Puzzling out the Middle-to-Upper Palaeolithic Transition

2 William E. Banks

3 UMR 5199 PACEA, CNRS, Université de Bordeaux, Pessac, France

4 e-mail: william.banks@u-bordeaux.fr

5 Standfirst: Homo sapiens remains, molecular data and a revised chronology for the Bulgarian site of

6 Bacho Kiro document the earliest known presence of our species in Europe, representing an important

7 jigsaw piece in the Middle-to-Upper Palaeolithic transition.

8 Sometime between 50,000 to 39,000 years ago, $H$. sapiens replaced autochthonous Neanderthal

9 populations, prompting two major questions for archaeologists today: when did H. sapiens enter the

10 European landscape and what processes were implicated in Neanderthals' disappearance? Both are

11 challenging to address via an ancient and fragmentary archaeological record, but timing our species'

12 entry into Europe would seem straightforward since it can be answered by dating human remains. This

13 has proven to be more complicated than it seems, which is why an early site with dateable materials and

14 good genetic preservation is such an important commodity. The Bulgarian site of Bacho Kiro offers just

15 this and is the subject of two studies published this week in Nature and Nature Ecology \& Evolution: in

16 Nature, a paper by Hublin et al examines $H$. sapiens genetic material from the site, and on page XXX of

17 Nature Ecology \& Evolution, a paper by Fewlass et al establishes this material as the earliest direct

18 evidence of our species in Europe.

19 Originally excavated in the 1970s, Bacho Kiro has long interested the archaeological community because

20 human remains (subsequently lost) associated its eponymous Initial Upper Palaeolithic (IUP) stone tool

21 industry--the "Bachokirian"--with H. sapiens. Hublin and colleagues ${ }^{1}$ report $H$. sapiens mitochondrial

22 DNA sequences from excavated bone fragments that proteomic screening identified as hominin. Fewlass 
23 et $\mathrm{al}^{2}$ provide direct dates on these fragments, in the framework of an extensive dating campaign at the

24 site targeting levels from which Bachokirian lithics and associated bone remains were recovered. This

25 dating project is particularly important because previous radiocarbon measurements from Bacho Kiro

26 are imprecise and stratigraphically inverted, rendering the site of limited use for dating $H$. sapiens arrival

27 in Europe. Fewless and colleagues' study employs cutting edge dating methods and two different

28 radiocarbon laboratories to obtain accurate and precise radiocarbon ages. They analysed these data

29 using Bayesian age modelling methods to better constrain the chronological intervals of the IUP

30 archaeological levels. First, via a simple application of Bayesian statistics, a ${ }^{14} \mathrm{C}$ calibration curve is used to

31 convert radiocarbon measurements into calendar dates. Of greater utility to archaeological

32 investigations is the use of Bayesian modelling methods that combine probabilistic temporal information

33 provided by calibrated radiocarbon dates with a priori information - that being the stratigraphic

34 ordering of radiometrically dated archaeological events - to improve our understanding of the timing

35 and duration of these archaeological events (Figure 1). With this approach, Fewlass et al demonstrate

36 that the Bachokirian industry at the site dates to roughly 46-44 cal ka BP (calibrated kiloanni before

37 present).

38 These modelled ranges of the newly obtained radiocarbon measurements agree with the molecular date

39 ranges calculated by Hublin et al on the human bones. Thus, these human remains from Bacho Kiro

40 currently reflect the earliest direct evidence of our species in Europe. Aside from Bacho Kiro, the directly

41 dated human remains from the site of Peştera cu Oase (Romania) at ca. 41 cal ka BP represent the oldest

42 known modern human presence in Europe ${ }^{3}$, although claims for early presence have been made based

43 on human remains from Kent's Cavern (UK) ${ }^{4}$ and Grotta del Cavallo (Italy) ${ }^{5}$. These last two sites,

44 however, are plagued with problems of archaeological association-meaning that the human remains

45 themselves are not directly dated, and their associations with dated faunal and marine shell remains,

46 respectively, are equivocal ${ }^{6,7}$. The direct dates on human remains in a larger, well resolved chronology ${ }^{1,2}$ 
47 from Bacho Kiro are of particular importance because they provide solid evidence that modern humans

48 were present in south-eastern Europe by 46,000 years ago, and that these populations were responsible

49 for IUP assemblages at this site.

50 This is not to say, however, that the site's levels containing the Bachokirian industry are free from the

51 contextual problems with which archaeologists are often confronted. Fewlass et al explain that a small

52 assemblage of IUP artefacts is contained in the upper portion of Layer N1-J and propose that modern

53 human use of the cave began as early as 47k cal ka BP. However, the stratigraphic profile showing piece-

54 plotted artefacts from the different levels (Supp. Fig. 4) ${ }^{2}$ illustrates that the stratigraphic contact

55 between Layers N1-J and N1-I is not as distinct as described ${ }^{1}$, and thus the original context of the dated

56 bones from N1-J, and their association with modern humans, is open to debate. Furthermore, the

57 mtDNA from an undated $H$. sapiens molar, also recovered from the upper portion of $\mathrm{N}^{1-J^{1}}$, is genetically

58 identical to one of the dated modern human bone fragments from the overlying Layer N1-I, suggesting

59 that this tooth was originally associated with the level above. Therefore, when inferring the earliest

60 modern human presence at Bacho Kiro, it is most prudent to focus on the lower age-modelled boundary

61 for Layer N1-I, which is roughly $46 \mathrm{cal}$ ka BP, rather than the older limits of the modelled age ranges from

62 the upper part of underlying Layer N1-J or the unmodelled calibrated date for the oldest modern human

63 bone fragment (CC7-335).

64 The results summarized and discussed above are important because we as archaeologists ultimately wish

65 to understand the population and cultural dynamics implicated in the observed disappearance of

66 Neanderthal populations in Europe around 40-39 cal ka BP. It is important to keep in mind, nonetheless,

67 that some of the characteristics of the data we use to investigate these issues render the task

68 challenging. For example, a precise and detailed understanding of the timing of $H$. sapiens entry into

69 other regions of Europe is complicated by the fact that ${ }^{14} \mathrm{C}$ ages for this period typically have standard

70 errors of ca. 450 years meaning that at two standard errors (95\%), our temporal window is almost 2000 
71 years. This is not to say that we cannot effectively characterize our species' entry into other regions of

72 Europe and understand if ${ }^{8}$ and how $^{2,9}$ subsequent cultural interactions influenced the behaviours of

73 culturally complex ${ }^{10}$ autochthonous Neanderthals, although such an undertaking will be a difficult one.

74 These new results from Bacho Kiro provide us with an important piece of the puzzle, but many still

75 remain to be put in place.

76

77 William E. Banks

78 UMR 5199 PACEA, CNRS, Université de Bordeaux, Pessac, France

79 e-mail: william.banks@u-bordeaux.fr

80 Fig. 1. Hypothetical stratified archaeological sequence covering the late Middle and Initial Upper

81 Palaeolithic periods. Contacts between archaeological levels are often porous with artefacts potentially

82 migrating between levels as a result of post-depositional processes (freeze-thaw cycles, rodent

83 burrowing, etc.) such that associations between dated items and cultural material are not always

84 unequivocal. Radiocarbon age uncertainties can make it difficult to precisely discern archaeological

85 chronology without Bayesian methods. The latter rely on stratigraphic information and calibrated

86 radiocarbon dates to refine our understanding of the timing and duration of archaeological level

87 formation.

88

89 References

90 1. Hublin, J.-J. Initial Upper Palaeolithic Homo sapiens remains from Bacho Kiro Cave (Bulgaria). Nature 91 (2020). 
92 2. Fewlass, H. New $14 \mathrm{C}$ chronology for Middle-to-Upper Palaeolithic transition at Bacho Kiro Cave,

93 Bulgaria. Nat. Ecol. Evol. (2020).

94 3. Zilhão, J. et al. The Peştera cu Oase People, Europe's earliest modern humans. in Rethinking the

95 Human Revolution (eds. Mellars, P., Boyle, K., Bar-Yosef, O. \& Stringer, C.) 249-262 (McDonald

$96 \quad$ Institute for Archaeological Research, 2007).

97 4. Higham, T. et al. The earliest evidence for anatomically modern humans in northwestern Europe.

$98 \quad$ Nature 479, 521-524 (2011).

99 5. Benazzi, S. et al. Early dispersal of modern humans in Europe and implications for Neanderthal

100 behaviour. Nature 479, 525-529 (2011).

101 6. White, M. \& Pettitt, P. Ancient Digs and Modern Myths: The Age and Context of the Kent's Cavern 4

102 Maxilla and the Earliest Homo sapiens Specimens in Europe. Eur. J. Archaeol. 15, 392-420 (2012).

103 7. Zilhão, J., Banks, W. E., d’Errico, F. \& Gioia, P. Analysis of Site Formation and Assemblage Integrity

104 Does Not Support Attribution of the Uluzzian to Modern Humans at Grotta del Cavallo. PLOS ONE 10,

$105 \mathrm{e} 0131181(2015)$.

106 8. d'Errico, F. The invisible frontier. A multiple species model for the origin of behavioral modernity.

107 Evol. Anthropol. Issues News Rev. 12, 188-202 (2003).

108 9. Ruebens, K., McPherron, S. J. P. \& Hublin, J.-J. On the local Mousterian origin of the Châtelperronian:

109 Integrating typo-technological, chronostratigraphic and contextual data. J. Hum. Evol. 86, 55-91

110 (2015).

111 10. Jaubert, J. et al. Early Neanderthal constructions deep in Bruniquel Cave in southwestern France.

$112 \quad$ Nature 534, 111-114 (2016). 


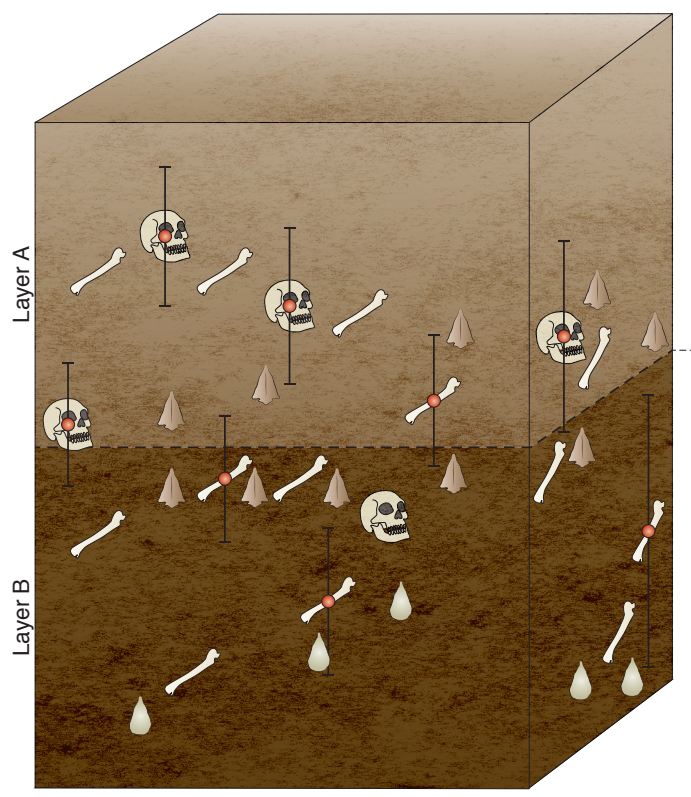

I ${ }^{14} \mathrm{C}$ age Human $\triangle_{\text {tool industry }}^{\text {Mousterian stone }}$

IUP stone
tool industry

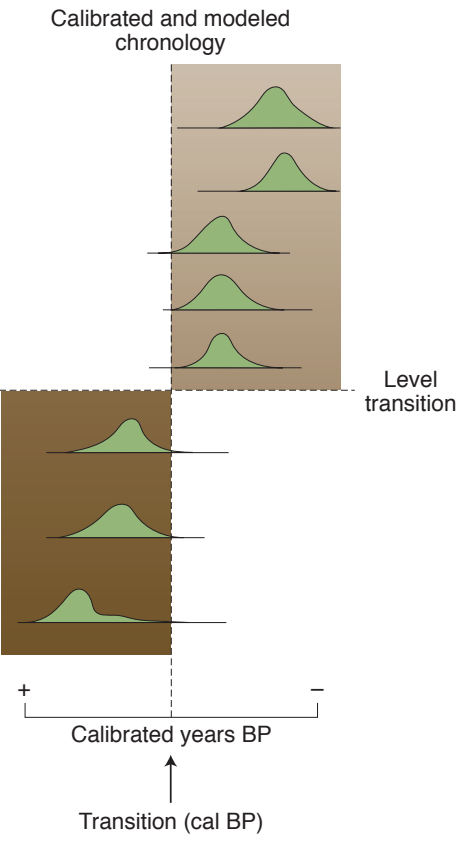

Transition (cal BP) 